\title{
Kepemimpinan Kristen Berdasarkan 1 Timotius 3:1-7
}

\author{
Ezra Tari ${ }^{1}$, Ermin Alperiana Mosooli ${ }^{2}$, Elsye Evasolina Tulaka ${ }^{3}$ \\ ${ }^{1}$ Sekolah Tinggi Agama Kristen Negeri Kupang \\ ${ }^{2,3}$ Sekolah Tinggi Teologi Star's Lub Luwuk Banggai \\ tariezra@gmail.com ${ }^{1}$,erminalperina@gmail.com ${ }^{2}$,evasolina@gmail.com ${ }^{3}$
}

\begin{abstract}
This article examines Christian leadership with integrity based on 1 Timothy 3: 17. This study departs from the condition of the leaders, both church leaders and leaders in general. Some leaders are no longer a figure or role model for their own families, people they lead and even society in general. With that problem, the authors describe the leader who is an example for everyone. The method used is a qualitative method. Based on the study conducted by the author, there are two important things that need to be learned, namely Leadership Model is without blemish, husband of one wife, can hold back, polite, wise, likes to give a ride, and inspires many people including the servants in Church. Furthermore, the leader has a good name inside and outside the congregation. This is evident from the activities of the leader himself. Therefore, this paper is a study of Christian leadership that highlights all aspects of the life of Christian leaders not only in the Church but in society.
\end{abstract}

Keywords: integrity; Christian leadership; leader's example; Timothy

\begin{abstract}
Abstrak: Artikel ini mengkaji tentang kepemimpinan Kristen yang berintegritas berdasarkan 1 Timotius 3:1-7. Kajian ini berangkat dari kondisi para pemimpin, baik pemimpin gereja maupun pemimpin pada umumnya. Beberapa pemimpin tidak lagi menjadi figur atau teladan bagi keluarganya sendiri, orang yang dipimpinnya bahkan masyarakat pada umumnya. Dengan persoalan itu maka, penulis memaparkan tentang pemimpin yang menjadi teladan bagi semua orang. Metode yang digunakan adalah metode kualitatif. Berdasarkan kajian yang dilakukan oleh penulis, maka ada dua hal penting yang perlu dipelajari, yakni Keteladanan pemimpin itu tidak bercacat, suami dari satu istri, dapat menahan diri, sopan, bijaksana, suka memberi tumpangan, dan menginspirasi banyak orang termasuk para pelayan-pelayan di Gereja. Selanjutanya, pemimpin itu memiliki nama baik di dalam dan di luar jemaat. Hal ini nampak dari aktiftas pemimpin itu sendiri. Oleh karena itu, tulisan ini merupakan studi kepemimpinan Kristen yang menyoroti seluruh aspek kehidupan pemimpin Kristen bukan hanya di dalam Gereja tetapi dalam masyarakat.
\end{abstract}

Kata Kunci: integritas; kepemimpinan Kristen; keteladanan pemimpin; Timotius

\section{Pendahuluan}

Argumen kuat untuk spiritualitas di tempat kerja dan kepemimpinan spiritual, model ilmiah yang menempatkan kepemimpinan spiritual dalam paradigma Yahudi-Kristen. Bahkan, banyak yang mengecam kelangkaan pekerjaan di bidang ini, yang menghubungkan ide-ide kepemimpinan berbasis Alkitab dengan pendekatan ilmiah sosial untuk kepemimpinan. Meskipun minat yang semakin besar dalam pendekatan spiritual dan pendekatan berbasis kepemimpinan. Perhatian khusus adalah kepemimpinan spiritual telah 
dikaitkan erat dengan kepemimpinan transformasional, pertanyaan tentang moralitas, khususnya para pemimpin dalam politik internasional yang membuat argumen bahwa moralitas tidak harus didasarkan pada istilah absolut tetapi diinformasikan oleh kehatihatian, fleksibilitas, dan kebaikan bersama yang ditentukan oleh pemenuhan kepentingan dalam jangka panjang.

Pemimpin haruslah memiliki sifat dan karakter sebagai berikut: 1. Bijaksana. 2. Tak bercacat. 3. Cakap mengajar. 4. Memiliki nama baik. 5. rendah hati. 6. Sopan. 7. Bukan peminum. Bagaimana relevansi ciri eksklusif kepemimpin Kristen bagi Generasi Z? Sebagai generasi yang sangat melek teknologi, tentulah tidak sulit bagi mereka untuk belajar sesuatu, mendapat pengetahuan dan menguji kebenaran. Oleh karena itu dibutuhkan kepemimpinan Kristen yang mau mendengar dan hadir bersama dengan mereka. Generasi $\mathrm{Z}$ sangat kritis kepada para pemimpin yang arogan dan merasa diri paling mampu atau tahu. Pola kepemimpinan yang deliberatif (melibatkan, setara dan tidak mengambil jarak) akan menjadi akses masuk untuk menjangkau generasi ini. Generasi $\mathrm{Z}$ juga membutuhkan contoh nyata dalam membangun bangsa. Gerakan sukarela yang digerakkan melalui media digital semakin menjamur. Mengajar generasi $\mathrm{Z}$ tidak cukup dengan teori atau doktrin tetapi dibutuhkan teladan. Para pemimpin kelompok kecil, penilik dan pengurus kampus akan menghadapi generasi ini. Tidak ada cara lain selain mengandalkan hikmat Tuhan dan bukan berusaha memaksakan pemikiran kita.

Kehidupan seorang pemimpin tidak hanya harus memiliki suatu kehidupan kerohanian yang tinggi tetapi juga harus ditunjang oleh integritas diri dalam kepemimpinannya. Bobot kepemimpinan tidak ditentukan oleh tingginya pendidikan semata atau banyaknya jam terbang dalam pelayanan, melainkan oleh integritas diri. ${ }^{1}$ Pecahnya Kerajaan Israel, hancurnya Kerajaan Yehuda adalah karena rapuhnya integritas para pemimpinnya. Keruntuhan masyarakat juga diawali dengan pemimpin yang kehilangan integritasnya, yang berakibat runtuhnya sendi-sendi norma masyarakat, seperti ayah tidak menjadi teladan, anak-anak mencari figur dari film, televisi dan media lainnya. Bahwa pemimpin yang berintegritas adalah pemimpin yang selalu mematutkan hidupnya dengan Firman Tuhan, bergantung penuh pada pimpinan Roh Kudus, mengusahakan karakter yang baik, dan selalu menunjukkan sikap kerendahan hati.

Gereja memerlukan pemimpin-pemimpin. "Jikalau tidak ada pemimpin, jatuhlah bangsa" (Ams 11:14). Gereja tidak akan bertumbuh mencapai kedewasaan, tanpa kepemimpinan (Ef. 4:11-16). Gereja yang tengah bertumbuh dan bergumul dalam dunia yang penuh goncangan dan krisis, memerlukan pimpinan yang solid, yang kekuatannya bertumpu pada asas-asas kepemimpinan yang Alkitabiah. Gereja yang menang dan sukses, berarti gereja yang memiliki kepemimpinan bervisi tajam, bermotivasi dasar yang benar,

\footnotetext{
${ }^{1}$ Desti Samarenna and Harls Evan R. Siahaan, "Memahami Dan Menerapkan Prinsip Kepemimpinan Orang Muda Menurut 1 Timotius 4 : 12 Bagi Mahasiswa Teologi," BIA': Jurnal Teologi dan Pendidikan Kristen Kontekstual 2, no. 1 (2019): 1-13, http://www.jurnalbia.com/index.php/bia/article/view/60.
} 
dengan strategi yang diarahkan oleh Firman dan Roh Kudus, serta paling penting: dalam otoritas Kepala Gereja Tuhan Yesus Kristus (Efesus 4:16).

Berdasarkan latar belakang di atas, maka penulis merumuskan masalah penelitian yaitu: bagaimana kepemimpinan Kristen berdasarkan 1 Timotius 3:1-7? Tujuan dari penelitian ini adalah untuk menemukan kepemimpinan Kristen berdasarkan 1 Timotius 3:1-7. Manfaat yang didapatkan dari hasil penelitian ini adalah: pertama mengembangkan kepemimpinan Kristen berdasarkan 1 Timotius 3:1-7. Kedua dapat mengatasi permasalahan kepemimpinan dalam lingkup Gereja dan sosial. Ketiga menolong para pemimpin untuk menerapkan kepemimpinan berdasrkan 1 Timotius 3:1-7..

\section{Metode}

Penulis menggunakan metode penelitian yang digunakan adalah Dalam menguraikan penelitian ini, penulis menggunakan metode penelitian penelitian kualitatif. Metode kualitatif bersifat deskriptif analisis. Talizaro Tafonao mengutip pendapat Sugiyono dalam buku metode penelitian manajemen (2014, p. 347), mengatakan bahwa metode penelitian kualitatif adalah dapat diartikan sebagai metode penelitian yang digunakan untuk meneliti kondisi objek yang alamiah, di mana peneliti berperan sebagai instrument kunci, teknik pengumpulan data dilakukan secara trianggulasi (gabungan). Sumber data yang dipakai dalam penelitian kualitatif berupa lingkungan alamiah.

\section{Pembahasan}

\section{Keinginan untuk Memimpin — 1 Timotius 3: 1}

Ayat 1a. Kata-kata pembukaan bagian ini mungkin merupakan lanjutan dari pokok pembahasan terakhir dari pasal 2 . Semua pemakaian lain dari pernyataan tersebut (1:15; 4:19; II Tim. 2:11; Tit. 3:8) tampaknya mengikuti atau mendahului berbagai pernyataan penting tentang doktrin Injil. Demikian pula di sini jika melahirkan anak dari 2:15 dianggap mengacu kepada kelahiran sang Juruselamat. Tampaknya inilah penafsiran yang lebih disukai. Paulus kemudian mengawali pembahasan mengenai persyaratan bagi penatua yang dilakukannya secara berurutan: persyaratan pribadi (ay. 2, 3). persyaratan menyangkut keluarga (ay. 4, 5), persyaratan mengenai sikapnya terhadap jemaat (ay. 5, 6), dan mengenai hubungannya dengan dunia non-Kristen (ay. 7). Pada bagian kedua sang rasul membahas persyaratan bagi kedudukan diaken dan diaken perempuan (ay. 8-13) yang sama dengan persyaratan bagi penatua.

Jabatan penilik jemaat. Satu kata; juga dipakai dalam Lukas 19:44: Kisah Para Rasul 1:20 dan I Petrus 2:12. Kata kerjanya muncul dalam Ibrani 12:15 yang menunjukkan bahwa fungsi pokok penatua merupakan tanggung jawab setiap orang percaya. Kata penilik jemaat dipakai dalam Kisah Para Rasul 20:28; Filipi 1:1; Titus 1:7; I Petrus 2:25. Jabatan penatua dan penilik jemaat itu sama: di dalam Titus 1:5, 7. Kedua kata ini dipakai untuk orang yang sama di dalam ayat-ayat yang berurutan. Orang yang menghendaki jabatan penilik jemaat menginginkan,dan seterusnya. Pertama. menghendaki, hanya dipakai di dalam ayat ini, 6:10 dan Ibrani 11:16. Keinginan sungguh-sungguh dari seseorang untuk 
memperoleh jabatan ini hendaknya seperti keinginan Abraham akan negeri surgawi. Kata yang satunya, menginginkan, lebih sering dipakai, dan juga mengungkapkan keinginan yang sungguh-sungguh (Ibr. 6:11; I Ptr. 1:12, Luk. 22:15).

Paulus memandang tinggi jabatan penilik jemaat, sehingga ia menetapkan syarat yang sepadan dengan kemuliaaan bagi orang yang ingin menjadi penilik jemaat. Mereka yang akan mengurus jemaat (ay.5) yang merupakan tiang penopang dan dasar kebenaran dunia (ay.14). "Benarlah perkataan ini”. Ungkapan ini dapat bertindak baik sebagai pernyataan penutup maupun sebuah pernyataan pembuka (lih 1 Tim 1:15; 3:1; 4:9; 2 Tim 2:11; Titus 3:8). Ini adalah pernyataan kedua dari lima pernyataan-pernyataan "dapat dipercaya" dalam Surat-surat Pastoral. Mereka berfungsi secara sintaksis seperti penggunaan Yesus akan suatu kata pengantar "amin" atau "amin, amin" (yang diterjemahkan "sebenar-benarnya," atau "sesungguh-sungguhnya"), menarik perhatian khusus pada pernyataan tersebut.

\section{Disiplin Kepemimpinan — 1 Timotius 3: 2-3}

Seorang penilik jemaat dituntut tidak bercacat artinya tidak mempunyai kekurangan di bidang etis. Suami dari satu istri artinya di samping istri yang hidup, pria itu tidak boleh mempunyai istri kedua atau melakukan perzinaan. Dapat menahan diri artinya tidak mudah terseret oleh hawa nafsu. Bijaksana, sikap yang telah dibarui Roh Kudus (bnd. Rm. 12:2). Sopan, sikap lahiriah yang anggun. Suka memberi tumpangan artinya bentuk nyata dari kasih di tengah-tengah situasi masyarakat, yang belum mempunyai fasilitas-fasilitas penginapan yang baik seperti zaman sekarang ini. Dalam budaya Toraja, hospitalitas pada tamu sangat dijunjung tinggi. Di mana tamu adalah raja. Setiap orang yang lewat ajakan untuk tinggal di rumah adalah hal yang sudah melekat dalam diri setiap orang. Meskipun itu adalah basa-basi. Namun prinsip mengajak tamu untuk tinggal di rumah adalah salah satu prinsip yang dipengang oleh setiap orang Toraja. Di mana orang Toraja memiliki keyakinan bahwa tamu yang datang itu membawa berkat bagi seisi rumah. Cakap mengajar, seorang pemimpin harus memiliki keahlian dalam mengajar orang lain. Seorang penilik harus member contoh kepada jemaatnya, bukan seorang peminum. Ia mampu berkomunikasi dengan baik. Ia tidak boleh seorang pemarah, artinya gampang marah melainkan seorang pendamai (bnd. Rm. 12:18).

Istilah "tidak bercacat" ini adalah kualifikasi kunci dari keseluruhan konteks untuk kepemimpinan di dalam gereja lokal. Frasa tersebut menyiratkan bahwa tidak ada pegangan untuk bisa dikritik, baik di komunitas yang percaya (1 Tim 3:2-6) dan di komunitas yang tidak percaya (1 Tim 3:7). Tema yang sama tentang tanpa cela ini diulang dalam ayat 7,10; 5:7; dan 6:14. Tidak ada pemimpin yang sempurna, namun ada orangorang percaya yang saleh, terhormat, dan dapat diterima. Lihat catatan di Titus 1:6.

\section{Demonstrasi Kepemimpinan - 1 Timotius 3: 4-7}

Seorang kepala keluarga yang baik, disegani dan dihormati oleh anak-anaknya maka ia dapat membian dengan baik jemaat. Tetapi jika tidak dapat mengurus rumah dengan baik 
maka tidak dapat mengatur jemaat dengan baik. Warga jemaat cenderung untuk memandang orang cakap dalam pelayanan karena semangat dan cintanya kepada Tuhan patut dicontoh. Bukan orang yang baru bertobat untuk menghindari sifat kesombongan. Kadangkala orang Kristen seolah-olah hidup dalam du dunia. Di lingkungan gereja hidup saleh namun di luar gereja berlaku keji.

"Dapat menahan diri " Ini secara harfiah adalah "sadar/siuman. "suka memberi tumpangan" Penginapan-penginapan di masa Paulus terkenal sebagai rumah-rumah pelacuran. "Cakap mengajar orang" Pemimpin harus bisa menjadi guru (lih 2 Tim 2:24). Menarik bahwa "mengajar" terdaftar sebagai karunia yang terpisah dalam 1 Korintus 12:28, namun terkait dengan karunia pendeta di Efesus 4:11. "Seorang kepala keluarga yang baik" Kepemimpinan bisa dilihat di rumah. Setiap jenis kesulitan antara suami dan istri atau anak-anak atau kakek-nenek atau mertua adalah dasar diskualifikasi dalam latarbelakang gereja mula-mula ini. "Janganlah ia seorang yang baru bertobat," Ini ditinggalkan di Titus. 1 Timotius ditulis ke Efesus, yang merupakan sebuah gereja yang mapan, sementara Titus ditulis ke Kreta, yang merupakan sebuah pekerjaan baru. "Hendaklah ia juga mempunyai nama baik di luar jemaat," Kepemimpinan harus dipandang sebagai orang yang jujur dan tulus oleh orang yang tidak percaya, yang oleh gereja dicoba dibawa kepada iman dalam Kristus (5:14; 6:1; Titus 2:5,6,10; 1 Kor 10:32; Kol 4:5; 1 Tes 4:12).

\section{Implikasi}

Tugas penting pemimpin gereja menurut surat 1 Timotius adalah: Pertama, pemimpin gereja harus memperingatkan bahaya penyesatan (1 Tim. 4:1-5) yaitu ajaran-ajaran salah yang terdapat di dalam jemaat. Kedua, pemimpin gereja harus mengurus jemaat dengan baik dan mengatur tata ibadat. Ketiga, pemimpin harus memperingatkan pentingnya doa; doa harus melibatkan semua orang (1Tim. 2:1), doa untuk para penguasa merupakan prioritas (1Tim. 2:2), doa harus didukung dengan hidup yang sesuai (1Tim. 2:8-10).

Dipilihnya beberapa anggota dari jemaat untuk mengisi kebutuhan jemaat demi melayani dengan sendirinya perlu memperhatikan talenta-talenta yang dimiliki demi mengisi kebutuhan tersebut. Seperti yang dijelaskan dalam Roma 12:1-8, masingmasing hendaknya melayani dengan talenta yang dimiliki. Pemahaman tersebut menunjukan bahwa pendataan jemaat menjadi syarat yang tidak dapat dihindari. Setiap jemaat hams mengenal dengan baik kebutuhan dan kekayaan telenta yang dimiliki. Dengan demikian talenta-telanta dalam jemaat tidak menjadi sia-sia. Kesuksesan pelayanan dalam jemaat juga tergantung pada sejauh mana jemaat tersebut mampu menggunakan talenta-talenta yang ada dalam jemaat.

Kesimpulan atas segala ajaran tentang pribadi dan karakter Kristen terdapat dalam Galatia 5:22,23,25. "Tetapi buah Roh ialah: kasih, sukacita, damai sejahtera, kesabaran, kemurahan, kebaikan, kesetiaan, kelemah-lembutan, penguasaan diri. Tidak ada hukum yang menentang hal-hal itu...jikalau kita hidup oleh roh,mbaiklah hidup kita juga dipimpin oleh Roh. Seorang pemimpin rohani harus mencontoh dan meneladani kehidupan dan 
keteladanan Tuhan semasa hidup dan pelayanan-Nya. Setiap pengajaran-pengajaran yang diberikan kepada setiap orang yang mendengar, haruslah dapat merubah hidup orang yang mendengarkan berita keselamatan itu dan menjadikan mereka ciptaan baru seperti yang Tuhan Yesus ajarkan. Hasil penelitian yang ditemukan oleh Katarina dan Krido Siswanto bahwa seorang pemimpin terutama pemimpin Kristen harus memiliki karakter seperti Yesus. Seseorang pemimpin Kristen pada masa kini harus mempunyai prinsip dalam kepemimpinan yakni membebaskan dan menggubah orang yang dipimpin dari belenggu dosa dan membawa kepada keselamatan kekal, sebagaimana yang tergambar dalam karakter Yesus.

Spiritualitas Kepemimpinan yang Baik baik dibuktikan dengan ada waktu pribadi untuk berdoa, ketekunan untuk mempelajari Kitab Suci, serta setia dalam pekabaran Injil. Kemampuan Manajemen dalam Memimpin menurut Iskandar dalam bukunya Management according to the Bible (2008, p. 50) memaparkan bahwa manajemen Kristiani merupakan manajemen yang didasarkan pada Firman Tuhan sebagaimana tertulis dalam Alkitab. Pelayanan dalam memimpin prinsip kepemimpinan Kristen ialah memimpin dengan kasih, sehingga akan berdampak kepada kepemimpinan yang melayani atau menjadi pelayan.

\section{Kesimpulan}

Instruksi Paulus untuk pekerjaan yang diinginkan, harus dilihat sebagai panggilan tanpa pamrih dan pengorbanan untuk melayani orang lain. Selain itu, pemimpin sepatutnya disiplin dalam karakter, mempertahankan tinggi standar moral. Kepemimpinan ini diidentifikasi dengan komitmen untuk mengendalikan diri dan penguasaan nafsu; dan mempraktekkan pengendalian diri terkait dengan uang, anggur, atau amarah yang keras. Pemimpin Kristen juga harus memiliki rekam jejak yang terbukti baik di rumah maupun di arena publik. Tentu saja ada kebutuhan untuk menguji pernyataan ini untuk menentukan kebenaran empiris mereka. Jangan sampai jatuh ke dalam jurang kaum realis yang percaya bahwa sifat manusia adalah egois dan orang akan berperilaku sesuai dengan pencarian kepentingan diri yang rasional.

\section{Referensi}

Adipranata, Daniel. "Ciri Eksklusif Kepemimpinan Kristen Dan Generasi Z - Perkantas Jakarta." Accessed June 4, 2019. https://perkantasjakarta.org/ciri-eksklusifkepemimpinan-kristen/.

Anggu, Peter. "Pertumbuhan Karakter Kristen” (n.d.). Accessed June 7, 2019. https://webcache.googleusercontent.com/search?q=cache:8IQasA6UQTwJ:https://me dia.neliti.com/media/publications/103241-ID-pertumbuhan-karakter-kristenkepribadian.pdf $+\& \mathrm{~cd}=14 \& \mathrm{hl}=\mathrm{id} \& \mathrm{ct}=\mathrm{clnk} \& \mathrm{gl}=\mathrm{id}$.

Bob Utley. “1, 2 TIMOTIUS Dan Titus.” Accessed June 5, 2019. http://www.freebiblecommentary.org/indonesian_bible_study.htm.

Budiman, R.. Tafsiran Alkitab: Surat-Surat Pastoral I \& II Timotius Dan Titus. Jakarta: BPK Gunung Mulia, 2008. 
Ginting, Christine Fuceria. "Konsep Kepemimpinan Penggembalaan Berdasarkan 1

Timotius Dan Aplikasinya Terhadap Pertumbuhan Rohani Jemaat." Accessed June 7, 2019. http://webcache.googleusercontent.com/search?q=cache:0L-

xN23MqbkJ:sttpantekostasumutaceh.ac.id/e-

journal/index.php/pneustos/article/viewFile/7/6+\&cd=15\&hl=id\&ct=clnk\&gl=id.

Handayani, Dessy. "Isu-Isu Kontemporer Dalam Jabatan Gerejawi." Accessed June 7, 2019.

http://webcache.googleusercontent.com/search?q=cache:cvot6_QTaTAJ:download.g aruda.ristekdikti.go.id/article.php\%3Farticle\%3D788419\%26val\%3D12952\%26title $\% 3 \mathrm{DIsu}-$

isu\%2520Kontemporer\%2520dalam\%2520Jabatan\%2520Gerejawi+\&cd=44\&hl=id \&ct $=$ clnk

Katarina; Krido Siswanto. "KETELADANAN KEPEMIMPINAN YESUS DAN IMPLIKASINYA BAGI KEPEMIMPINAN GEREJA PADA MASA KINI" (n.d.). Accessed May 28, 2019. https://journal.sttsimpson.ac.id/index.php/EJTI/article/download/102/pdf.\&gl=id.

Rukku, Maria; Daniel Ronda. "PEMIMPIN YANG MEMILIKI INTEGRITAS MENURUT 2 TIMOTIUS PASAL 2" (n.d.). Accessed June 4, 2019. https://webcache.googleusercontent.com/search?q=cache:xhKAktCCEacJ:https://me dia.neliti.com/media/publications/105014-pemimpin-yang-memiliki-integritasmenuru-5419c77e.pdf $+\& c d=14 \& h l=i d \& c t=c l n k \& g l=i d$.

Sabda. "1 Timotius 3:1 - Tafsiran/Catatan - Alkitab SABDA." Accessed June 4, 2019. https://alkitab.sabda.org/commentary.php?book=54\&chapter=3\&verse $=1$.

Samarenna, Desti, and Harls Evan R. Siahaan. "Memahami Dan Menerapkan Prinsip Kepemimpinan Orang Muda Menurut 1 Timotius 4 : 12 Bagi Mahasiswa Teologi." BIA': Jurnal Teologi dan Pendidikan Kristen Kontekstual 2, no. 1 (2019): 1-13. http://www.jurnalbia.com/index.php/bia/article/view/60.

Talizaro Tafona'o. "KEPRIBADIAN GURU KRISTEN DALAM PERSPEKTIF 1 TIMOTIUS 4:11-16 | Tafona'o | Evangelikal: Jurnal Teologi Injili Dan Pembinaan Warga Jemaat." Evangelikal: Jurnal Teologi Injili Dan Pembinaan Warga Jemaat Volume 3, Nomor 1. Last modified 2019. Accessed April 26, 2019. https://journal.sttsimpson.ac.id/index.php/EJTI/article/view/115/pdf.

Tari, Ezra. Teologi Tongkonan: Berteologi Dalam Konteks Budaya Toraja. Vol. 2, 2018. http://www.stttorsina.ac.id/jurnal/index.php/epigraphe.

Thomasson, Yoseph Christian; Jermia Djadi. "Kepemimpinan Yesus Kristus Menurut Injil Sinoptik Dan Relevansinya Terhadap Kepemimpinan Rohani Masa Kini” (n.d.). Accessed May 28, 2019. https://media.neliti.com/media/publications/104906kepemimpinan-yesus-kristus-menurut-injil-77aa2aa4.pdf.

Wakkary, Markus Daniel. “12 Prinsip Kepemimpinan Alkitabiah.” Accessed June 4, 2019. https://tokoh.id/publikasi/opini/12-prinsip-kepemimpinan-alkitabiah/.

Zai, Seni Iman. "KARAKTER HAMBA TUHAN SEBAGAI KONSELOR MENURUT 1 TIMOTIUS 3:1-7 Seni Iman Zai - PDF." Accessed June 4, 2019. https://webcache.googleusercontent.com/search?q=cache:blBcyu3r2k8J:https://docpl ayer.info/46959681-Karakter-hamba-tuhan-sebagai-konselor-menurut-1-timotius-31-7-seni-iman-zai.html+\&cd=9\&hl=id\&ct=clnk\&gl=id. 